\title{
Jesus, moral regeneration and crime in the Gospel of John
}

\author{
J.M. Johan Ras' \\ Department of Criminal Justice, University of Zululand, South Africa \\ jras@pan.uzulu.ac.za
}

\begin{abstract}
A structural and text-immanent approach to the Gospel of John reveals that Jesus of Nazareth came to earth to do the will of God his Father and to take away the sins of the world. The author/s makes/make it clear that Jesus taught Nicodemus that one needs to be born again in order to enter the kingdom of God. To be born again means that one must be born out of water and Spirit, that is, through becoming a follower or disciple of Jesus Christ, one's life has to change. This change, also called regeneration, is, anthropologically-speaking, according to the rational-choice theory, a deliberate choice made by man to become a follower or disciple of Jesus and to do his Father's will. The disciples are not called upon to be like robbers and thieves, focused on the accumulation of earthly wealth, but to love one another. Although Jesus was crucified because of an allegation of high treason, a crime against the state, He instructed his followers to forgive others and to remain in His love. In terms of the explicatio-applicatio model, the intended kerygmatic message of John to his intended readers is clear: he wants all people, including criminals, to believe in Jesus and to follow Him, because, according to the Johannine author/s, when one follows Jesus, one does not commit crime, because one has been morally regenerated.
\end{abstract}

Keywords: Jesus, moral regeneration, gospel of St John, crime, South Africa

\section{Introduction and problem}

South Africa has shocking crime statistics - more than two million serious criminal cases have been opened at police stations around the country in the past financial book year (Ras, 20I0a). This reality is a huge problem because people live in fear and overseas investors do not easily come to invest in our country to create much-needed jobs and wealth (Ras, 2009). This situation necessitates that every concerned individual needs to change the present state of affairs so that serious crime can be reduced drastically. I believe this can only happen if people decide not to do crime and to choose and follow good moral values like in the Bible.

\section{Research approach}

In this article the researcher follows a structural and text-immanent approach (Ras, 1996, pp. 17-19; Van Aarde, 1994, pp. 26-27; Van der Merwe, 1999, pp. 267, 282) to the $\varepsilon v \alpha \gamma \gamma \varepsilon \lambda$ iov $\kappa \alpha \tau \alpha$ I $\omega \alpha \nu v \eta \nu$ (Gospel of John) in order to see what the Fourth Gospel has to say about Jesus, moral regeneration and crime. This research is not a philosophical attempt to speculate or an exposition of the structural and text-immanent approach - it only uses this approach to read the Gospel of John in order to see what the Greek text of the Gospel of John, through its lexical-syntactical structures, has to say about this topic (cf. Louw \& Nida, 1988; Ras, 1996).

This approach to the Fourth Gospel reveals that Jesus of Nazareth came to earth to do the will of God his Father (cf. John 6:38) and to take away the sins of the world (cf. John I:29). The doing of His Father's will is directly connected in this Gospel to the call to mankind to believe in God's Son (that is, Jesus), so that they can have $\xi \omega \eta v \alpha$ coviov ("eternal life" John 3:15-16; 6:38-40; Westcott, 1924, pp. 54-55, 103). Eternal life is directly connected in the Gospel to regeneration (John 3:3-5).

According to John, John the Baptist, who was send $\pi \alpha \rho \alpha \theta \varepsilon$ ( "from God" - John I:6), has pointed out Jesus, who is

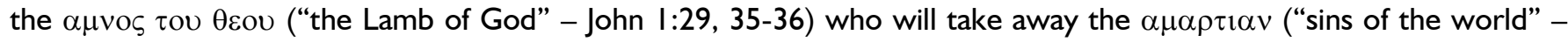
John I:29; Nestle-Aland 1979). An in-depth look at the Gospel of John further reveals that followers of Jesus do not commit crime because they are born again. This practically means today that if a person is born again, he/she will not do crime. From a pisteological (believer's) point of view this again will lead to a reduction in the crime rate.

\section{Nicodemus, the readers, and regeneration}

From an anthropological-analytical perspective, John chapter three (starting at John 2:23 to 3:22) is the locus classicus of regeneration in the Fourth Gospel (Ras, 1987). In a concise but very powerful textual narrative the author depicts a conversation that took place between Jesus, the Son of God, and Nicodemus, who is described as $\varepsilon \kappa \tau \omega v$

I. Johan Ras, D Phil, is an Associate Professor and Head of the Department of Criminal Justice at the University of Zululand, South Africa. Johan has a strong academic background in Theology. 


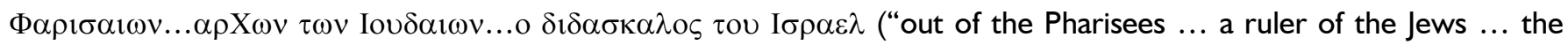
teacher of Israel" - John 3:I, 10; Nestle-Aland, 1979).

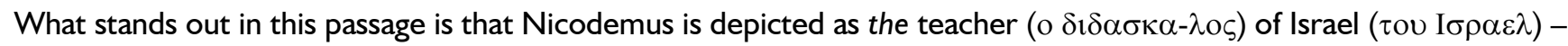
not just a teacher, but the teacher - in contemporary language, the teacher par excellence, like an academic professor in Jewish historical studies and literature. It is also depicted in John chapter three that this Nicodemus was representing the Pharisees and that he was sent to Jesus on their behalf (John 3:I-2, 7, II-I2; 7:46-52; Duvenhage, s.a., pp. 154-I6I).

Lenski (1961, pp. 228-229) pointed out that Nicodemus was a member of the Sanhedrin. This body consisted of seventy top Jewish members that were regarded as the highest religio-political authority of the Jews (Duvenhage, s.a., pp. 145-I Within this body, Nicodemus was regarded as one of the best, the best of the best, in other words, simply outstanding (Ras, 1987; 2010a).

The Johannine author/s states/state that it was this Nicodemus who had originally been confronted and challenged by Jesus through His (Jesus's) thought-provoking remark that no man can enter into $\tau \eta v \beta \alpha \sigma \imath \lambda \varepsilon \imath \alpha v$ tov $\theta \varepsilon \circ v$ ("the kingdom of God - John 3:5) except/unless he/she is $\gamma \varepsilon v v \eta \theta \eta \alpha v \omega \theta \varepsilon v$ ("born again" - John 3:3), more specifically "born" $\varepsilon \kappa ~ v \delta \alpha \tau o \zeta$

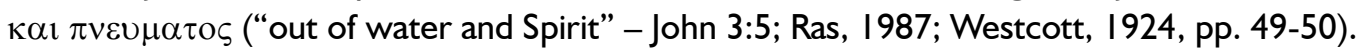

According to the immediate and remote context (lexical-syntactical textual context - John I:6-52; 2:23-4:2), $\gamma \varepsilon v v \eta \theta \eta$ $\alpha \nu \omega \theta \varepsilon v$ or regeneration refers, anthropologically-speaking, according to the rational-choice theory, to the deliberate choice, made by man, to become a follower or disciple of Jesus and to do his Father's will (John I:35-37, 44; 6:38-40; 7:37; 8:12, 28; 10:7-9, 16, 27; 12:26, 46; 15:8, 16-17; 20:21-23, 30-31; 21:22; Ras, 1987).

John's intended/implied reader audience, the actual first (historical) readers of this Gospel, consisting probably of Jewish and Hellenistic elements (Lombard, 1998, p. 498), as well as the modern readers, us, are confronted and challenged by this narrative (Ras, 20I0a). The rhetoric of the text confronts contemporary readers to visualize this conversation, to listen to the textual voices, to think, and to also make a decision - in short, through the Gospel, we are confronted through the text with the Master's voice, to make a choice, the right choice, and that is, to become a believer,

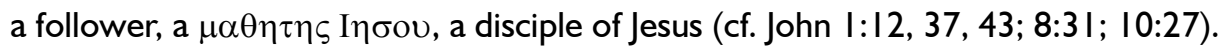

From an etymological point of view, to be a $\mu \alpha \theta \eta \tau \eta \varsigma$ means someone has become a student or learner of Jesus. Students or learners in ancient times followed their Masters and observed their words and deeds. Through active following and also through typical participant-observation ("experiential learning", often with the implication of reflection) they later broadened their knowledge and insight and accumulated the necessary wisdom and practical skills to cope with life and all its challenges in a multifaceted way (Ras, 2010a). The Hebrew word רסל ("lamad", "learn") forms the Grundbedeutung of the Greek word $\mu \alpha \theta \eta \tau \eta \varsigma$ as used by the Fourth Gospel's author/s (Abbott-Smith, 1977, pp. 275, 277; Arndt \& Gingrich, 1975, pp. 486-487; Koehler \& Baumgartner, 1958, pp. 482-483; Louw, Nida, Smith \& Munson, 1988, Vol. I, pp. 327-328, 47I).

\section{Discipleship and regeneration}

Discipleship during the time of John the Baptist, Jesus, and the early church, meant that people deliberately, in line with the rational-choice theory, made the decision to follow Jesus and then actually followed him physically and spiritually. From a pragmatic point of view, according to John, initiation started visibly with baptism (John I:7, 25-28, 35-37, 43-44; 3:5, II, 22-23, 32; 4:I-2; Ras, 1987; Dods, 1979, p. 713).

Although discipleship had started with the decision to follow Jesus and to believe in Him, true faith is manifested through the entering of the baptismal waters, depicting the follow-ing of the Baptist, and/or Jesus. The expression $\varepsilon \kappa$ $v \delta \alpha \tau o \zeta \kappa \alpha 1 \pi v \varepsilon v \mu \alpha \tau \sigma \zeta$ ("out of water and spirit" - John 3:5) refers to this reality (Arndt \& Gingrich, 1975, p. 840; Lenski, 1961,pp. 236-238; Ras, 1987, pp. 168-221). In the Fourth Gospel, the water symbolizes, indirectly, the break between a sinful past and a new future where a person's sins are washed away. In short, through following Jesus through baptism one visibly left his or her sins behind (Ras, 1987).

From a theological point of view the Johannine soteriology ("salvation") is all about $\pi 10 \tau 1 \varsigma$ "faith" in Jesus (cf. John 3:II-18), but this faith consists of a birth out of water and Spirit. The expression $\varepsilon \xi \nu \delta \alpha \tau 0 \varsigma \kappa \alpha 1 \pi v \varepsilon v \mu \alpha \tau o \varsigma$ refers cotextually to the baptism of John the Baptist and Jesus (Lenski, I96I, pp. 237-238) where followers had been immersed in water, had confessed their sins (cf. John I:29; 3:25; after their decision to become a follower and to believe in God who would give them the Holy Spirit (cf. John I:3I-33; 3:22-23; 4:I-2; Ras, 1987).

According to John, becoming a disciple equals becoming a believer, in other words, one only can be a believer if one is a disciple and vice versa. The water $(\nu \delta \omega \rho)$ is joined with the Spirit $(\pi v \varepsilon v \mu \alpha)$ because the former is the divinely chosen earthly medium and the latter the regenerating agent which uses the water as medium (cf. Lenski, 196I, p. 237). John pointed out that the Holy Spirit, through the making of a disciple, changed the lives of people so that they became "born 
again believers', that is, they were spiritually and morally transformed to become followers or disciples of Jesus (John 3:3, $5,15-16,36)$.

The Jesus-Nicodemus narrative states that becoming a disciple is a visible action-event that is called $\mu \alpha \rho \tau \nu \rho 1 \alpha-$ "a testimony" (John 3:I I). Through the plural "we-say-ings", Jesus said to Nicodemus: "I tell you the truth, we speak of what

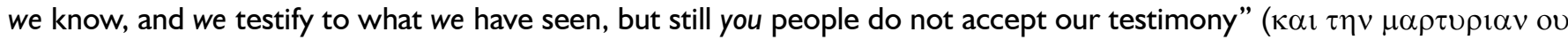
$\lambda \alpha \mu \beta \alpha v \varepsilon \tau \varepsilon)$. The Johannine author/s has/have made it clear that Jesus had spoken on behalf of Himself, his followers and John the Baptist, addressing Nicodemus who was depicted as representing the Pharisees who earlier had rejected the teachings of John the Baptist and his advice to follow Jesus, the Christ (the Messiah) (John I: 19, 23-26, 29-34; Ras, 1987).

In other words, according to the Fourth Gospel, moral regeneration is directly linked through the Jesus-Nicodemus narrative with discipleship. In praxis, one is regarded as morally regenerated once one has become a disciple or follower of John the Baptist and/or Jesus, the Messiah (the Christ) through water and Spirit (Ras, 1987; John 2:23-4:2, especially John $3: 3,5,11-12$, I5-18, 22-23, 25-26, 32-33, 36).

\section{Discipleship and crime}

The Fourth Gospel is quite clear that followers of the Baptist and Jesus are people who are walking in the light and not in darkness (John I:5-13; 3:3-5, 16-19) - it is people who are born out of God (born out of water and Spirit) because they have accepted the teachings of the Baptist and/or Jesus (cf. John I:I2-I3; 3:3-5, I I, I6-2 I). To walk in the light inter alia means not to do evil - it is to do what is right, to do the truth, that is, to act according to the will of God, as he has revealed Himself in and through His only begotten Son, Jesus Christ. In short, the followers of Jesus remain in His teachings, and this means they do not get involved in crime (John I:18; 5:19; 8:31, 44-45; 10:I-I0). The new command that Jesus gave to His followers, "to love one another" would be the visible sign to outsiders that they were His disciples (cf. John 13:34-35).

Although the Johannine author/authors does not/do not directly write about crime, there are indirect references to different crimes. Jesus is portrayed saying that those who do not know him have the Devil as father and they want to do

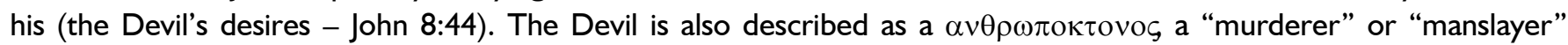
(Abbott-Smith, 1977, p. 38) “... from the beginning." He (the Devil) is also "lying” and is regarded as a liar (John 8:44). In terms of contemporary crime terminology, crimes like murder, assault with the intention to do grievous bodily harm $(\mathrm{GBH})$, uttering, fraud, and perjury, for example, come to mind when one reads John chapter eight from a criminological and criminal law perspective.

In John 10: I-10 Jesus is depicted, for example, as $\eta \theta v \rho \alpha \tau \omega \nu \pi \rho o \beta \alpha \tau \omega \nu$ ("the door/gate of the sheep"). John says that Jesus said: "I tell you the truth, the man who does not enter the sheep pen by the gate, but climbs in by some other way, is a thief and a robber ... I tell you the truth, I am the gate for the sheep. All who ever came before me were $\kappa \lambda \varepsilon \pi \tau \alpha \mathrm{l}$ $\kappa \alpha_{1} \lambda \eta \sigma \rho \alpha_{1}$, thieves and robbers ... The thief comes only to steal and kill and destroy ..." (John 10:10). Through these metaphors and illustrations it becomes clear to the readers of the Fourth Gospel that the followers of Jesus are like Him.

They are not, by implication, like the thieves and the robbers who are there only to steal, to kill, and to destroy (John 10:8-10). The references to theft and robbery in the above-mentioned passage, for example, indicate that the followers of Jesus, those that are disciples, morally regenerated members of His flock (John $21: 15-17$ ), are people who are by implication not involved in acts (cf. Snyman, 2008, p.30), that today, in terms of the fields of criminal law, criminology, police science and penology, are regarded as crimes.

When Jesus was arrested, He was taken to the political governor's palace, the palace of military governor, Pontius Pilate (John 18:28). Although Pilate found Jesus innocent on the religious charge laid by the Jews, that He (Jesus) had made Himself the Son of God (cf. John 10:30, 33; II:46-50; 19:6- I6), he was afraid of the Jews who shouted that if he would let Jesus go, he was no friend of Caesar (cf. John 18:33-39; 19:1-3, I2, I4-15, 19-21). In terms of criminal law, specifically Roman law, Jesus was crucified because he was erroneously accused of the crime of high treason, originally known as perduellio, and later as crimen laesae maiestatis (cf. Snyman, 2008, p. 3 I I; Duvenhage, s.a., p. 160).

It was made clear to the intended readers of the Fourth Gospel that Pontius Pilate handed Jesus over to die because the Jews accused Jesus of making himself uiov $\theta \varepsilon$ ov ("the Son of God" - John 19:7), that is, a "heavenly King" (cf. John 18:36-37), and anyone who did anything like this was regarded as actually challenging the authority of the State, in this case the power of Emperor or Caesar Tiberius (Blaiklock, 1980, Vol. 5, p. I38; Duvenhage, s.a., pp. 39-42); something that constitutes high treason (Duvenhage, s.a., p. 160).

What had persuaded Pilate to hand Jesus over for crucifixion was the recorded Greek words that the Jews had

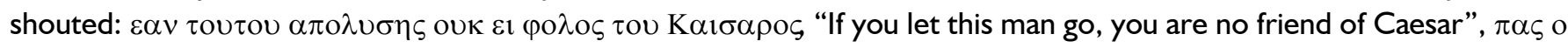

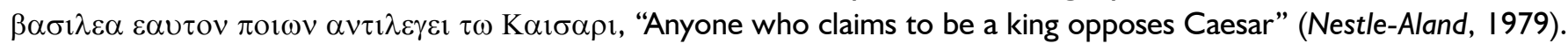

Inkanyiso, Jnl Hum \& Soc Sci 2010, 2(2) 
The fear that he would allow a form of high treason to go unpunished, and that he (Pilate) would laterreap the consequences of this decision, had convinced him to hand Jesus over to the people's will.

The first readers of the Johannine Gospel were all well acquainted with all the typical crimes that had occurred during the time of the Roman Empire, and they knew very well, when they had heard the words of the Fourth Gospel, that they were called to believe in Jesus, to become His followers, and not to do anything that was not a manifestation of His love and in line with His teachings. Concerning crime, the disciples knew that when they were called to follow the Baptist and/ or Jesus, they were to behave like people who are born again, who bear fruit, would forgive others, and would love one another (John 3:3,5; 15:12, 16-17; 20:23), and not to get involved with any form of crime.

\section{The purpose of the Fourth Gospel, the call to discipleship, and crime}

Why the Gospel of John has been written, is from a text critical point of view a crux interpretum because of two possible textual variants related to the word "believe." According to John 20:30-31: "Jesus did many other miraculous signs in the presence of his disciples, which are not recorded in this book. But these are written that one may believe that Jesus is the Christ, the Son of God, and that by believing one may have life in his name" (John 20:31). The words "so that you may believe" can also be substituted with the words "so that you can continue to believe."

If $i v \alpha \pi \imath \sigma \tau \varepsilon v \sigma \eta \tau \varepsilon$ (the aorist verb) is chosen it means that the Gospel is written to unbelievers who are called upon to believe in Jesus, but if $1 v \alpha \pi 1 \sigma \tau \varepsilon \cup \eta \tau \varepsilon$ (the praesens verb) is chosen, then it means that the Gospel is written to believers who are called upon to continue to believe in Jesus. The majority of textual readings favour the variant $\pi 1 \sigma \tau \varepsilon v \sigma \eta \tau \varepsilon$, "(so that you) may believe", but it is not the oldest reading. This textual variant can be dated from the middle of the third century A.D. to the $15^{\text {th }}$ century A.D. (cf. $\mathrm{x}^{2}, \mathrm{~A}, \mathrm{C}, \mathrm{D}, \mathrm{L}, \mathrm{W}, \Psi, 0100, f^{1.13}$, and the Majority Text), while some of the oldest readings ( $\mathrm{P}^{66 \mathrm{vid}}, \mathrm{N}^{2}, \mathrm{~B}, \Theta, 0250,892^{\mathrm{s}}$ ) have the variant $\pi 1 \sigma \tau \varepsilon \cup \eta \tau \varepsilon$ ("so that you can continue to believe") (cf. NestleAland, 1979, p. 317).

Whatever decision is taken with regard to this textual crux, the fact remains that the first readers of the Gospel, whether they were unbelievers, or disciples that had formed part of the early church, that is, they were part of Jesus' flock (John 10:7, II, 14-16, 26-28; 21: 15-17), were quite aware of what was expected of them. According to John, what was expected from the intended and first readers, and also those after them, was to follow Jesus and His teachings, and this definitely excluded any act or deed (like crime) that was not in line with God's will.

\section{Explicatio-applicatio}

The explicatio-applicatio model is normally used in hermeneutics and in homiletics (the art of preaching) when it comes to Bible exposition. One first has to say what the text meant in the past (explicatio) and then one has to apply its principles (applicatio) to the present for contemporary listeners/hearers (Robinson, 1983, pp. 20-30; Stott, 1983, p. 10). When this model is applied to the Gospel of John, then the intended kerygmatic message of the whole book is clear: John wanted all people, including criminals, to believe in Jesus and to follow Him (cf. John 3:15-16), because when they do so they will not do deeds that are outside His will - acts that will include what we today will regard as crime.

By hearing the words of the Fourth Gospel, the first readers would have regarded any criminal act or deed as part of the $\varphi \alpha \nu \lambda \alpha$, "evil" (cf. John 3:20). John 3:20 states: "Everyone who does evil ( $\varphi \alpha \nu \lambda \alpha$ ) hates the light, and will not come into the light for fear that his deeds will be exposed." The Johannine references to "evil/evil deeds (John 3:19), thieves

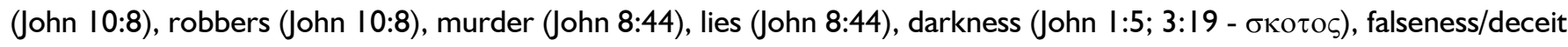

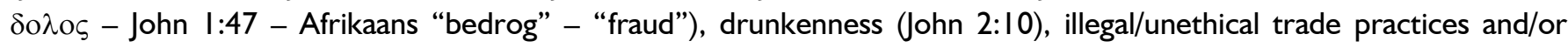
money-making schemes (cf. John 2:I4-I5), are typical examples of what the readers knew would not carry God's, and Jesus', approval. In short, disciples do not commit crime and do not get involved in criminal activities and/or practices (Ras, 2010a).

\section{South African crime statistics}

During the 2009 / 2010 book year (I April 2009 to 3I March 2010) the following reported crimes occurred in South Africa:

\begin{tabular}{llll}
\hline Robbery with aggravated circumstances & 113755 & Attempted murder & 17410 \\
Assault with the intention to do grievous bodily harm & 205293 & Car hijackings & 13902 \\
Truck hijackings & 1412 & Motor vehicle and motor cycle theft & 71776 \\
Cash-in-Transit & 358 & Bank robbery & 93 \\
Robbery at business premises & 14534 & Robbery at residential premises & 18786
\end{tabular}




\begin{tabular}{llll} 
Street robberies & 72194 & Shoplifting & 88634 \\
Murder & 16834 & Illegal possession of firearms & 14542 \\
Common assault & 197284 & Driving under the influence or drugs & 62939 \\
Sex offences & 68332 & Arson & 6701 \\
Burglary at residential premises & 256577 & Theft out of motor vehicle & 120862 \\
\hline
\end{tabular}

In short, 2 I 2 I 887 (approximately 2, I million) serious criminal cases have been reported to the police during this period (South African Police Service, 2009 / 2010; Ras, 2009, p. 179; http:///www.saps.gov/za/statistics/reports/crimestats/2010/ categories/illegal_pos_firearm_ammunition.pdf). What makes these figures shocking is the fact that we have a total population of about 49052489 people, comprising 79\% Black Africans, 9.6\% Whites, $8.9 \%$ Coloureds, and $2.5 \%$ Indian /Asian. There are 16275424 males and 15984 I8I females between the age group 15 to 64 years - the age group responsible for the majority of crimes (https/www.cia.gov/library/publications/the-world-factbook/geos/sf.html).

There is no doubt in the minds of concerned citizens that the moral fibre of many South Africans is eroded. The high crime rate indicates that there is no respect for others, their possessions, their lives and that the acts of criminals have a huge impact upon our society. Snyman (2008, pp. 21-29), who wrote from a criminal law perspective, is of the opinion that the criminal justice system is at present dysfunctional and has pointed out in 2008 that: "Never before in the peacetime history of this country has the value of human life been lower than since the introduction of the 'right to life'... and the abolition of the death penalty."

From a moral point of view South Africa, when it comes to many of its people, is bankrupt, morally sick and simply decadent. It seems that sound individual and family values, that all contribute to a healthy society, are going down the drain, and that the country as a whole suffers because of people's inability to act with integrity, sincerity, and to reveal ubuntu and humanitarian feelings like sharing and caring. Although less crime was reported during the 2010 Soccer World Cup, it seems at present that what is needed is inter alia a total new transformation in the hearts and minds of every human being that is concerned about the future of Madiba's rainbow nation (Ras, 2010a).

\section{Jesus, moral regeneration and crime}

From a Christian point of view, is clear that the author/s of the Fourth Gospel has / have indicated through the JesusNicodemus narrative that Jesus said that people must be born again in order to enter the kingdom of God (John 3:3, 5). In terms of the explicatio-applicatio model, as used in hermeneutics and homiletics (Robinson, 1983, pp. 20-30), the kerygmatic message of this Biblical passage is still applicable to Christians who believe that these words still have value and meaning for their and other people's daily lives (Ras, 1987; Stott, 1983, p. 162).

To stop the erosion of a morally bankrupt society, followers of Jesus have a soteriological message that has stood the test of time. From a pneumatological point of view, it is the Spirit of God that can work in and through man to transform their minds, hearts and hands (John 3:5, 8; cf. Heyns, 1978, pp. 305-307). Deliberate attempts by disciples of Jesus, via kerygmatic means, within family and societal circles, to bring the soteriological message of the Fourth Gospel across, may result, according to John, in a spiritual and moral transformation when it comes to man, and, one can add, anthropological and societal issues (Ras, 2010a).

Although any religion that promotes sound human and healthy moral values may assist to transform our existing society into a more peaceful one (cf. Harris, 2008:80), within Christian circles, the central message of God's love, as he

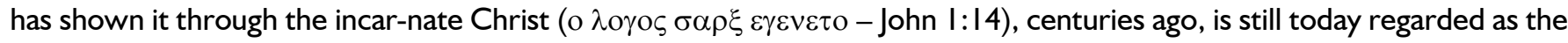
most powerful one (Ras, 2010a). The message of love, like John 3:16, "For God so loved the world...", and the new command of Jesus, "Love one another, as I have loved you, so you must love one another" (John I3:34), is in my opinion the master key to unlock evils, like crime and any form of injustice, in our society and to open doors to a better future.

\section{Different kinds of crime and informal social control}

The following crimes are, for example, typical examples of what lower, regional and higher courts, and magistrates and judges encounter in South Africa: crimes against the state (like high treason, sedition, public violence), and crimes against the administration of justice (like contempt of court, defeating or obstructing the course of justice, perjury, subornation of perjury, making conflicting statements under different oaths, making false statements in an affidavit, escaping from custody, obstructing police in the performance of their duties) (Snyman, 2008, pp. x-xi).

Other crimes include: crimes against the community (sexual crimes like general sexual crimes, rape, compelled rape, sexual assault, compelled sexual assault, compelling another to watch sexual acts, exposing genital organs, anus or breasts ("flashing"), displaying child pornography, engaging sexual services for reward (prostitution), incest, bestiality, a sexual act Inkanyiso, Jnl Hum \& Soc Sci 2010, 2(2) 
with a corpse, sexual offences against children, sexual offences against mentally disabled persons); crimes against the family (like bigamy and common-law abduction); crimes against public welfare (like corruption, extortion, drug offences, unlawful possession of firearms or ammunition, concealment of births, participating in criminal law activities, public indecency, violating a grave, violating a corpse) (Snyman, 2008, p. xi).

Further crimes include: crimes against a person (crimes against life, like murder, culpable homicide, administering poison or another noxious substance, exposing an infant); crimes against bodily integrity, (like assault, intimidation or pointing of a firearm); crimes against dignity and reputation (like crimen iniuria, , e.g. the Reitz four, criminal defamation); crimes against freedom of movement (like kidnapping); crimes against property (crimes relating to appropriation of property (like theft, removal of property for use, robbery, receiving stolen property, inability to give account of possession of goods suspected of being stolen, receiving stolen property without reasonable cause); fraud and related crimes (fraud, forgery and uttering, theft by false pretences); crimes relating to damage to property (like malicious injury to property, arson, housebreaking with intent to commit a crime, possession of housebreaking implements, trespass) (Snyman, 2008, p. xii).

The present reality of the above-mentioned crimes in the South African law and judicial system indicates that our past history has taught us that most people, who have not sound moral values, very easily can make the wrong choices and commit crime. Not only must proactive / preventative and reactive policing measures, as part of formal social control, be in place to cut down on crime, but most important, informal social control that is based upon the socialization process, must be in place. Informal social control is where every member of society behaves himself / herself and control their own desires and actions in order not to commit any form of crime (Van Heerden, 1995; Ras, 2010a).

The role of parents, teachers, principals, church leaders, traditional leaders (like izindunas and amakhosi), role models, and inspirational sport and community leaders are vital in this regard. Through an internalization of good moral and human values, persons at an early (young) stage need to be shaped, formed and moulded to conform to the general expected norms, values and laws of society. Sound religious values, like showing respect to others and their belongings, to love God and other human beings, to be considerate, to show compassion, to help those in need, to carry the burdens of those that are weak, to develop others in a positive and meaningful way, to strive to life a Godly life and to set good moral standards that will inspire others, and so forth, are typical examples of matters that will assist to achieve this desired state of affairs (cf. Ras, 2010b, pp. 2I-32).

\section{Practical application}

Combrink (1998, p. 306) correctly pointed out that South Africa needs a credible church; a body that is trustworthy and sincere because people have lost hope because of all the deceit and continuing corruption. The believers, followers of Christ, the church, should serve as a model and this can only be done if it is living in close communion with its living Lord and in obedience to His calling. When it comes to crime, it is quite clear that people want to see and experience a much more safer South Africa, like during the 2010 Soccer World Cup.

From a Christian perspective, getting the message of moral regeneration, the John 3:5 message, across, as we find it in the Jesus-Nicodemus narrative in the Fourth Gospel, practically means that followers of Jesus (the Church), must not only spread this soteriological message with zeal and commitment, but also with persuasion. The Church or disciples are called to be the salt of the earth and the light of the world (Matthew 5:13-14), that is, to be different and to make a difference to set an example, not to get involved in crime, and to serve as role models when it comes to good and sound moral values.

It is in especially the inner circles of the family, friends, the church, the school, and in the broader circles of business, the community and in government, that the well-known words of John the Seer, needs to reverberate, because it in within these circles that positive moral transformation of heads, hearts and hands needs and has to take place. He said:

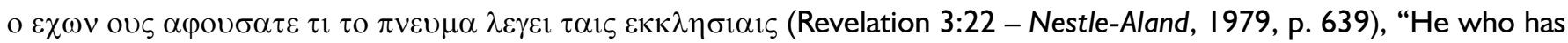
an ear, let him hear what the Spirit says to the churches." Why? Because the disciples of Jesus (the Church) are called to lead by example when it comes to sound moral values and good behavior or conduct.

\section{Conclusion}

According to John, the author/s of the Fourth Gospel, followers of Jesus do not commit crime. When a person is born again (John 3:5), he or she is spiritually transformed and has moved from the darkness into the light (John 3:19-2I), to no longer do his/her own will, but the will of God, as He has revealed himself in Jesus. Commitment to Jesus, means commitment to change. The high crime rate in South Africa necessitates that we who have ears, need to listen, and must bring about change, because, if those who listen and understand do not do it, who will? 
The old Latin saying impunita non debent esse admissa, "crimes should not go unpunished” (Van der Westhuizen, I996, p. 40I), must be taken seriously today, but more important, we need to change those who want to commit crime through the preaching of the word of God, because through the proverbial praedicatio verbi dei, that is, through "the preaching of the Word of God", the $\pi v \varepsilon v \mu \alpha$ and the $v \delta \omega \rho$, the Spirit and the water (John 3:5), can become soteriological agents of change in the lives of human beings, because, in terms of the Jesus-Nicodemus discourse, atonement is sufficient for all, because: "God so loved the world that he gave his only begotten Son, so that whoever believes in Him, should not perish, but have eternal life" (John 3:16).

\section{References}

Abbott-Smith, G. (1977). A Manual Greek Lexicon of the New Testament. Latest impression. Edinburgh, Scotland: T. \& T. Clark.

Arndt, W.F. \& Gingrich, F. W. (1975). A Greek-English Lexicon of the New Testament and other Early Christian Literature. Eighteenth impression. Chicago: The University of Chicago Press.

Blaiklock, E.M. (1980). Roman Empire, I33-I4I, in Tenney, M.C. (Ed.), The Zondervan Pictorial Encyclopedia of the Bible, Vol. 5. Grand Rapids, Michigan: Zondervan Publishing House.

Combrink, H.J.B. (1998). The rhetoric of the church in the transition from the old to the new South Africa: socio-rhetorical criticism and ecclesiastical rhetoric. Neotestamentica. Journal of the New Testament Society of South Africa 32(2):289- 307.

Die Bybel. (1983). Vierde uitgawe (Naslaan) 1957. Kaapstad: Bybelgenootskap van Suid-Afrika.

Duvenhage, S. (s.a.). Die dékor van die Nuwe Testament. 'n Kultuur-historiese Agtergrondstudie. Pretoria: Interkerklike Uitgewerstrust.

Harris, G. (2008). The potential of nonviolence in building security in sub-Saharan Africa. African Security Review I7(2):76-92. June 2008. Pretoria: Institute for Security Studies.

Heyns, J.A. (1978). Dogmatiek. Pretoria: N. G. Kerkboekhandel.

Koehler, L. \& Baumgartner, W. (1958). Lexicon in Veteris Testamenti Libros. Leiden: E. J. Brill.

Lenski, R.C.H. (196I). The Interpretation of St. John's Gospel. Minneapolis, Minnesota: Augsburg Publishing House.

Lombard, H.A. (1998). Orthodoxy and other-wordliness of the church: Johannine perspectives on Christianity in a new South Africa. Neotestamentica. Journal of the New Testament Society of South Africa, 32(2):497-508.

Louw, J.P., Nida, E.A., Smith, R.B. \& Munson, K.A. (I988). Greek-English Lexicon of the New Testament Based on Semantic Domains. Vol. I. Introduction \& Domains. New York: United Bible Societies.

Nestle-Aland. (1979). Novum Testamentum Graece. Ed. XXVI. Compilers: K. Aland, M. Black, C. M. Martini, B. M. Metzger \& A. Wikgren. Stuttgart: Deutsche Bibelstiftung.

Ras, J.M. (1987). “Nikodemus... dit is water en Gees!” Johannesburg: PPK-Uitgewers.

Ras, J.M. (1996). Die wederkoms van Christus in die Matteusevangelie. Doktorale proefskrif. Stellenbosch: Universiteit van Stellenbosch.

Ras, J.M. (2009). Managing in a downturn: Police remarks from a South African perspective. Law Enforcement Executive Forum, 9(5): $177-188$.

Ras, J.M. (2010a). Personal beliefs, opinions and views of the author in the light of his past training and experiences in church and policing circles.

Ras, J.M. (20IOb). Empower Pakistan: Detonating the Minds of Pakistan Females. Pakistan Journal of Criminology 2(2):2l-32. April 2010.

Robinson, H.W. (1983). Biblical Preaching. The Development and Delivery of Expository Messages. Eight printing. Grand Rapids, Michigan: Baker Book House.

Snyman, C.R. (2008). Criminal Law. $5^{\text {th }}$ edition. Durban: LexisNexis.

South African Police Service, 2009/2010. http:///www.saps.gov/za/statistics/reports/crimestats/2009/categories/ illegal_pos_firearm_ammunition.pdf). Retrieved May 19, 2010].

Stott, J.R.W. (1983). I believe in preaching. Fifth impression. London: Hodder and Stoughton.

The Holy Bible. New International Version (NIV-Bible). (1990). Third impression. Cape Town: Bible Society of South Africa.

Van Aarde, A.G. (1994). God-with-us. The dominant perspective in Matthew's Story and other essays. Hervormde Teologiese Studies. Supplement 5. Pretoria: Periodical Section of the Nederduitsch Hervormde Kerk van Afrika.

Van der Merwe, D.G. (1999). The historical and theological significance of John the Baptist as he is portrayed in John I. Neotestamentica. Journal of the New Testament Society of South Africa, 33(2):267-292.

Van der Westhuizen, J. (1996). Forensic Criminalistics. Second edition, first Impression. Johannesburg: Heinemann.

Van Heerden, T.J. (1995). Introduction to Police Science. Latest edition. Pretoria: UNISA.

Westcott, B.F. (1924). The Gospel according to St. John. Seventeenth impression. Manchester: Sherratt \& Hughes Printers. 